\title{
JC70: a new monoclonal antibody that detects vascular endothelium associated antigen on routinely processed tissue sections
}

\author{
D V Parums, J L Cordell, K Micklem, A R Heryet, K C Gatter, D Y Mason
}

\begin{abstract}
A new monoclonal antibody, JC70, raised against a membrane preparation from a spleen affected by hairy cell leukaemia, recognises a membrane bound glycoprotein identical with that of the CD31 group of monoclonal antibodies. The antibody stains a fixation resistant epitope on endothelial cells in benign and malignant conditions in a wide variety of paraffin wax embedded tissue. JC70 stained malignant endothelial cells in 10 angiosarcomas with more consistency than monoclonal or polyclonal antibodies to factor VIII related antigen (FVIII-Rag). In four cases of Kaposi's sarcoma the antibody stained malignant endothelial cells but not spindle cells.

It is concluded that antibody JC70 is of value for studying benign and malignant human vascular disorders in routinely processed tissue.
\end{abstract}

Vascular endothelial cells have an important role in coagulation, inflammation, immunity, regulation of vascular tone and in a wide variety of synthetic and metabolic functions. Endothelial cells also have a pivotal role in immunological diseases, angiogenesis in tumours, transplantation rejection, atherogenesis and placentation. ${ }^{1}$ Their role in health and disease is therefore of interest to histopathologists, and for this reason it is important to be able to recognise these cells in routine tissue sections. Morphologically, endothelial cells can be difficult to distinguish from other cell types and although a variety of markers is available to diagnostic histopathologists all have serious limitations.

Vascular endothelial cells can cause both benign and malignant tumours. Angiosarcomas, although rare, pose a diagnostic problem for histopathologists as they are tumours with varying morphological patterns. Vascular differentiation may be absent and they may be mistaken for other soft tissue sarcomas or for undifferentiated carcinomas. Staining of these tumours with antibodies to FVIII-related antigen (FVIII-Rag) has been disappointing with reports of lack of staining $^{23}$ and of cross reactions with carcinomas. ${ }^{4}$ Ulex europaeus agglutinin lectin shows variable staining of angiosarcoma cells ${ }^{5}$ and is not specific for endothelial cells, binding to squamous cell carcinomas and synovial sar$\operatorname{comas}^{6}$ as well as to neoplasms arising from colonic epithelium. ${ }^{7}$
There is therefore a need for a marker of benign and malignant endothelial cells of cardiovascular origin which will work reliably on routinely processed, paraffin wax embedded tissue. In this paper we report the production of a new monoclonal antibody JC70 which recognises normal and malignant vascular endothelial cells in routinely processed tissue and we evaluate its role in routine diagnostic practice.

\section{Methods}

PREPARATION OF ANTIGEN

Human spleen from a patient with hairy cell leukaemia was used as a source of antigen. Crude membranes were prepared by a modification of the method of Standring and Williams. ${ }^{8}$ Briefly, frozen tissue $(100 \mathrm{~g})$ was homogenised in $2.5 \%$ Tween $40,20 \mathrm{mM}$ TRIS-HCl, pH $7.5(200 \mathrm{ml})$, and centrifuged at $3000 \times g$ for 20 minutes. The supernatant was centrifuged at $40000 \times g$ for 30 minutes to sediment the membrane fraction which was washed before being used for immunisation. All buffers contained $1 \mu \mathrm{g} / \mathrm{ml}$ leupeptin, 1 $\mu \mathrm{g} / \mathrm{ml}$ pepstatin, $1 \mathrm{mM}$ phenyl methyl sulphonyl fluoride and $1 \mathrm{mM}$ iodoacetamide.

\section{CHARACTERISATION OF THE ANTIGEN}

RECOGNISED BY JC70

A crude membrane fraction was prepared using the method described above from a spleen from a patient with idiopathic thrombocytopenic purpura (which had been found by immunostaining to be rich in the antigen). Antigen recovery was measured by the alkaline phosphatase-antialkaline phosphatase (APAAP) technique ${ }^{910}$ to material vacuum dot blotted on to nitrocellulose sheets.

Essentially, all of the antigen in a 2\% NP40 extract of the crude membrane preparation bound to a lentil lectin Sepharose (Pharmacia) column. Antigen in the NP40 extract was eluted with $1 \mathrm{M}$ methyl glucoside in $1 \%$ NP40, TRIS- $\mathrm{HCl}$ ( $\mathrm{pH} \mathrm{7.5),} \mathrm{and} \mathrm{dialysed} \mathrm{to}$ remove the methyl glucoside. A second preparation from normal human platelets was prepared in a similar manner.

SODIUM DODECYL SULPHATE POLYACRYLAMIDE GEL ELECTROPHORESIS AND IMMUNOBLOTTING The membrane glycoprotein preparation (100 $\mu \mathrm{l}$ from $200 \mathrm{mg}$ of tissue) was precipitated with $10 \%$ trichloroacetic acid, the precipitate washed with acetone and solubilised by boiling in SDS-PAGE sample buffer ${ }^{11}$ containing $4 \mathrm{M}$ urea. This material was analysed on a $7 \cdot 5 \%$ 
gel $^{11}$ and the separated proteins were electroeluted on to a nitrocellulose sheet and stained for JC70 antigen by the APAAP technique.

\section{MONOCLONAL ANTIBODY PRODUCTION}

Tween membrane preparations were washed in a $150 \mathrm{mM}$ sodium chloride solution and the pellet was resuspended in $10 \mathrm{ml}$ of $10 \%$ formol saline and left rotating at room temperature for 30 minutes. Membranes were spun in a microfuge at $13000 \mathrm{rpm}$ for five minutes and then washed twice in physiological saline. The membrane pellet was resuspended in $20 \mathrm{ml}$ of physiological saline, aliquoted, and stored at $-20^{\circ} \mathrm{C}$ until required for use.

Balb/c mice were immunised three times intraperitoneally at 10 day intervals with $50 \mu \mathrm{g}$ of antigen in physiological saline. Cell fusion was performed by conventional techniques. ${ }^{12}$

For cytological preparations, routine peripheral blood smears were obtained from the haematology department. Slides were air-dried overnight and stored at $-20^{\circ} \mathrm{C}$. They were fixed before use in buffered formol acetone.

\section{TISSUE SECTIONS}

Fresh tissue

Frozen samples of tonsil and spleen were retrieved from storage at $-70^{\circ} \mathrm{C}$, sectioned on a cryostat, fixed and immunostained as described previously. ${ }^{10}$

Fixed tissue

Tissue sections were prepared from routine blocks stored in the Nuffield Department of
Pathology, John Radcliffe Hospital, Oxford. All tissues were fixed in unbuffered formol saline before paraffin wax embedding. For convenience in screening paraffin wax embedded specimens, some multiblock preparations were prepared as previously described. ${ }^{13}$

Sections from a range of benign vascular lesions were examined together with 10 angiosarcomas and four Kaposi's sarcomas (table). Normal tissues examined were skin and its appendages, placenta, testis, thyroid, cervix, uterus, stomach, small intestine, colon, lung, spleen, tonsil, lymph nodes, bone marrow, liver, bladder, kidney, adrenals, myocardium, aortic valve, vein and aorta. Sections of benign, non-vascular tumours included uterine leiomyoma, meningioma, and neurofibroma. Malignant tumours examined were squamous cell carcinoma of skin, malignant melanoma, carcinoma of lung (24 cases), adrenal carcinoma, transitional cell carcinoma of bladder, hepatoblastoma, non-Hodgkin's lymphomas (eight $\mathrm{T}$ cell and $20 \mathrm{~B}$ cell), leiomyosarcoma and fibrosarcoma.

\section{IMMUNOENZYMATIC LABELLING}

Tissue sections were stained with the mouse monoclonal antibody $\mathrm{F} 8 / 86 / 3$ raised against human FVIII-Rag ${ }^{14}$ and with antibody JC70 using the APAAP method. Before immunostaining paraffin wax sections were dewaxed, hydrated, and then incubated for about 30 minutes in $0.1 \%$ trypsin solution in $0.1 \%$ calcium chloride solution ( $\mathrm{pH} \mathrm{7 \cdot 8)}$.

Tissue sections were stained with rabbit polyclonal antibody to human FVIII-Rag

Reactions of endothelial markers on routinely processed tissue sections

\begin{tabular}{|c|c|c|c|c|c|c|}
\hline \multirow[b]{2}{*}{ Diagnosis } & \multirow[b]{2}{*}{ Site } & \multirow[b]{2}{*}{ No } & \multirow[b]{2}{*}{$J C 70$} & \multicolumn{2}{|l|}{$\begin{array}{l}\text { Antibody } \\
\text { FVIII-Rag }\end{array}$} & \multirow[b]{2}{*}{$U E A$} \\
\hline & & & & Monoclonal & Polyclonal & \\
\hline \multicolumn{7}{|l|}{ Vascular tissues } \\
\hline Acute thrombus & Vein & 1 & ++ & ++ & ++ & + \\
\hline Organising thrombus & Vein & 1 & ++ & ++ & $+t$ & + \\
\hline Pyogenic granuloma & Skin & 2 & ++ & $+t$ & ++ & ++ \\
\hline Capillary haemangioma & Skin & 1 & ++ & $+t$ & $+t$ & $+t$ \\
\hline Cavernous haemangioma & Skin, liver & 2 & ++ & ++ & ++ & ++ \\
\hline Angiofibroma & Nose, lung & 3 & ++ & + & ++ & $+t$ \\
\hline Angiokeratoma & Skin & 2 & $+t$ & ++ & + & ++ \\
\hline Angioleiomyoma & Thigh & 1 & ++ & $t+$ & $+t$ & ++ \\
\hline Angiolipoma & Skin & 4 & ++ & ++ & $+t$ & $+t$ \\
\hline Glomus tumour & Skin & 2 & + & ++ & + & + \\
\hline Haemangiopericytoma & Skin & 1 & ++ & + & ++ & + \\
\hline Chemodectoma & Carotid & 1 & + & + & + & + \\
\hline Atrial myxoma & Atria & 3 & ++ & + & + & ND \\
\hline Lymphangioma & Skin & 4 & - & ++ & + & + \\
\hline Lymphoepithelial cyst & Skin & 1 & - & + & + & ND \\
\hline Pneumatosis coli & Rectum & 1 & - & + & ++ & ++ \\
\hline Submucosal venous dilatation & Rectum & 1 & + & + & + & ++ \\
\hline Atherosclerosis & Carotid artery & 1 & ++ & ++ & ++ & ++ \\
\hline Cystic hygroma & Neck & 2 & + & ++ & + & + \\
\hline $\begin{array}{l}\text { Intravascular papillary } \\
\text { endothelial hyperplasia }\end{array}$ & Vein & 1 & ++ & ++ & ++ & ++ \\
\hline Angiodysplasia & Colon & 2 & ++ & ++ & ++ & ++ \\
\hline \multicolumn{7}{|l|}{ Angiosarcoma } \\
\hline & Liver & 1 & ++ & + & + & + \\
\hline & Rectum & 1 & ++ & \pm & \pm & \pm \\
\hline & Rectum & 1 & $\stackrel{+}{+}+$ & $\bar{t}$ & $\frac{ \pm}{t}$ & $\begin{array}{l}+ \\
+\end{array}$ \\
\hline & $\begin{array}{l}\text { Rectum } \\
\text { Breast }\end{array}$ & 1 & $+t$ & + & $\begin{array}{l}+ \\
+\end{array}$ & $\frac{T}{t}$ \\
\hline & Scalp & 1 & + & \pm & \pm & \pm \\
\hline & Axilla & 1 & ++ & $\bar{t}$ & $\bar{t}$ & \pm \\
\hline & Vein & 1 & + & ++ & + & $\bar{t}$ \\
\hline & $\begin{array}{l}\text { Skin of leg } \\
\text { Skin }\end{array}$ & $\begin{array}{l}1 \\
1\end{array}$ & $\begin{array}{l}++ \\
++\end{array}$ & $\frac{ \pm}{t}$ & $\frac{ \pm}{t}$ & $\frac{ \pm}{t}$ \\
\hline \multirow{5}{*}{ Kaposi's sarcoma } & Sxin & & & & & \\
\hline & Skin & 1 & + & \pm & + & \pm \\
\hline & Lymph node & 1 & ++ & + & + & $\bar{t}$ \\
\hline & Skin & 1 & ++ & + & + & + \\
\hline & Rectum & 1 & + & - & + & + \\
\hline
\end{tabular}

$-=$ No detection of endothelial antigen; $+=$ focal endothelial antigen staining; $++=$ uniform endothelial antigen staining; $\pm=$ antigen staining on normal endothelium but not malignant cells; ND $=$ not done. 


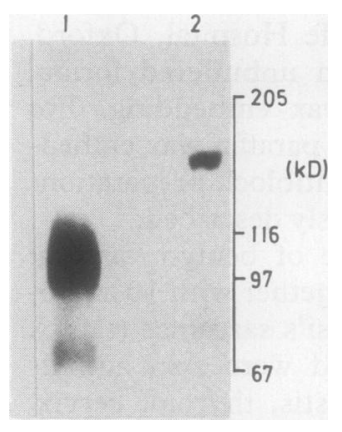

Figure 1 Western blot of the antigen recognised by antibody JC70 is shown to have a relative molecular mass of 100000 from spleen (track 1) and 130000 from platelets (track 2).
(Dakopatts $\mathrm{A} / \mathrm{S}$ ) using an indirect peroxidase method, as described previously. ${ }^{15}$ Tissue sections were stained with Ulex europaeus agglutinin lectin according to the method of Holthöfer. ${ }^{16}$

\section{Results}

BIOCHEMICAL CHARACTERISATION OF THE JC70 ANTIGEN

Essentially all of the antigen recognised by antibody JC70 was found in the NP40 soluble membrane protein which bound to lentil lectin. This preparation contained about $43 \%$ of the antigen and $0.6 \%$ of the total protein present in the tissue homogenate (constituting an enrichment of 70-fold). This indicates that the antigen is a membrane glycoprotein. On Western blotting the antigen was shown to have a relative molecular mass of 100000 from the spleen (fig 1, track 1) and 130000 from the platelet preparation (fig 1 , track 2 ). This pattern was identical with a blot using an antiCD31 monoclonal antibody.

\section{REACTIONS OF JC70 ON BLOOD SMEARS AND CRYOSTAT SECTIONS}

On peripheral blood smears (fig 2) antibody JC70 labelled several different cell types, including neutrophil polymorphs, $50 \%$ of the lymphocytes, and all of the monocytes and platelets. On tonsil and spleen the striking feature was the intense labelling of endothelial cells, but some non-endothelial cells were weakly labelled including mantle zone B cells and $T$ cells (fig 3 ).

\section{REACTIONS OF JC70 ON PARAFFIN WAX EMBEDDED} TISSUE SECTIONS

Normal tissues

Antibody JC70 reacted with endothelial cells in a wide range of normal tissues (figs 4-7). Staining was generally comparable with that using polyclonal and monoclonal antibodies to FVIII-Rag, but JC70 also stained endothelium

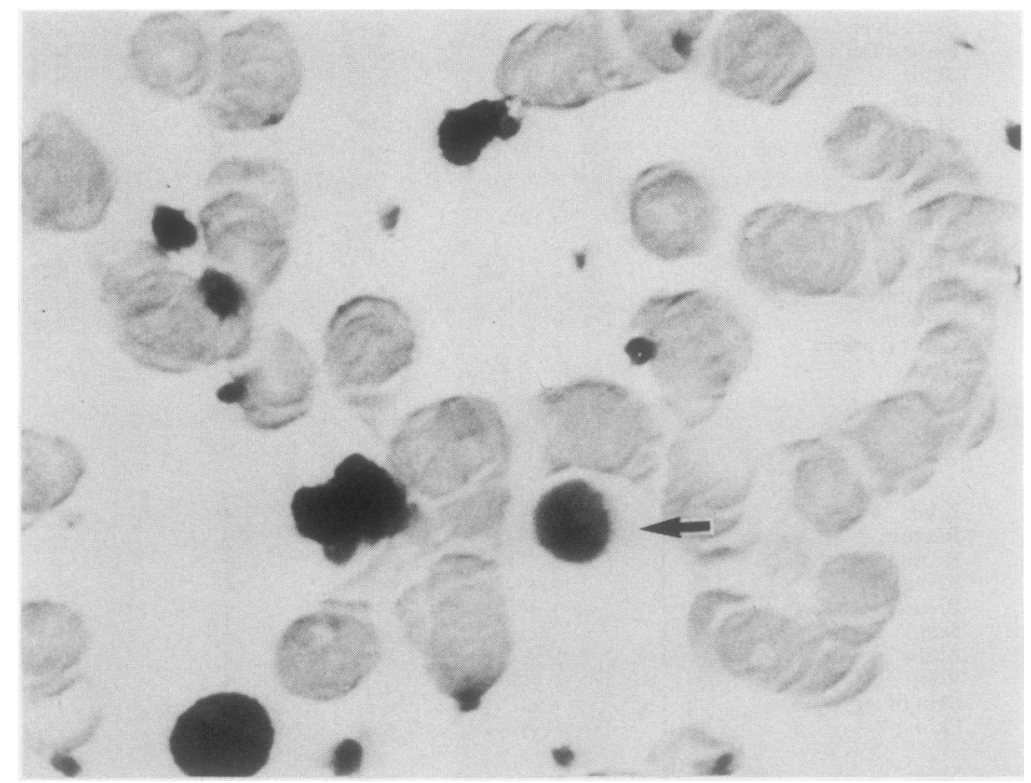

Figure 2 Peripheral blood smear showing labelling of platelets and many mononuclear cells. Note that not all lymphocytes are stained (arrow). in renal glomerular capillaries and the endothelium of vasa vasorum. JC70 also labelled megakaryocytes and occasional plasma cells in bone marrow. Staining of plasma cells was not seen in any other sections. Ulex europaeus agglutinin lectin stained normal endothelial cells but also a wide variety of other cells and particularly connective tissue.

\section{Vascular proliferations}

Benign: Antibody JC70 stained endothelial cells in a variety of benign vascular lesions more consistently than the monoclonal and polyclonal antibodies to FVIII-Rag. It did not stain lymphatic endothelium in the cases of lymphangioma, lymphoepithelial cyst and pneumatosis coli (table); anti-FVIII-Rag and Ulex europaeus agglutinin lectin gave variable, focal staining. JC70 stained endothelial cells in capillaries in a case of haemangiopericytoma as well as tumour cells outside vessels. The antibody stained numerous endothelial cells as well as "myxoma" (stromal) cells in three cases of atrial myxoma. The endothelial cells lining sinusoids of the liver, spleen, and lymph nodes were stained more reliably with JC70 than with antibodies to FVIII-Rag or with Ulex europaeus agglutinin lectin.

Angiosarcomas: Antibody JC70 stained malignant vascular endothelial cells in 10 cases of angiosarcoma (table) (figs 7A-C). Staining of malignant endothelial cells was more uniform with JC70 than with antibodies to FVIII-Rag or with Ulex europaeus agglutinin lectin and seemed to be more intense than on normal endothelium. Moreover, JC70 showed little of the intense background staining exhibited by antibodies to FVIII-Rag and Ulex europaeus agglutinin lectin in areas of haemorrhage and necrosis, which tended to mask any positive staining of tumour cells.

Kaposi's sarcomas: Antibody JC70 gave variable staining of small vessels in four cases of Kaposi's sarcoma but spindle cells in the stroma were unlabelled (table). Occasional stromal spindle cells were labelled by polyclonal and monoclonal antibodies to FVIIIRag.

\section{Non-vascular tumours}

In both benign and malignant tumours of nonvascular origin antibody JC70 stained endothelial cells in normal vessels but not tumour cells. The same pattern of staining was seen with antibodies to FVIII-Rag and with Ulex europaeus agglutinin lectin.

\section{Discussion}

Factor VIII related antigen is commonly used as a marker for vascular endothelial cells. ${ }^{17}$ It is not uniformly distributed among species. In man it is found in endothelial cells or arterioles, capillaries, and venules of many tissues including high endothelial vessels in lymphatic tissue and liver sinusoids. It is absent from glomerular capillaries, and splenic sinusoids express it only weakly. ${ }^{18}$ FVIII-Rag is also found in platelets, megakaryocytes, mast cells and the mesangial region of renal glomeruli. 
Figure 3 Cryostat section of tonsil illustrating monoclonal antibody JC70 staining vascular endothelium (arrow), but also lymphocytes in the mantle zone $(M Z)$. Lymphocytes elsewhere, including the germinal centre (GC) are unlabelled.

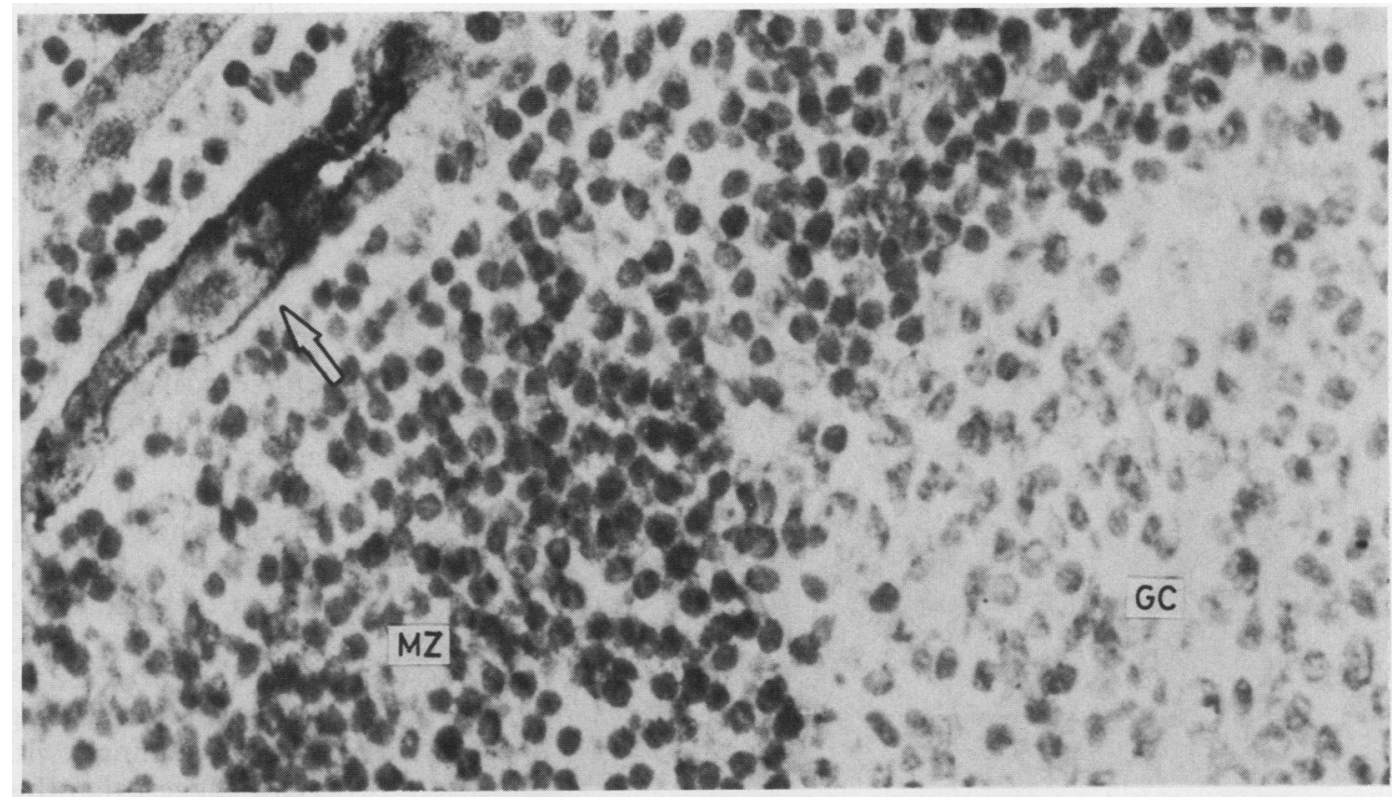

It is not reliably detectable in routinely processed material and has been reported by some workers to show lack of specificity, sensitivity, and reproducibility, particularly when using polyclonal preparations. ${ }^{419}$

Ulex europaeus agglutinin is a lectin that reacts with $\alpha$-L-fucose and was originally thought to be selective for vascular endothelial cells. It is now known to bind to L-fucose residues in other cell types. ${ }^{16}$ It has been claimed to be a more sensitive marker than FVIII-Rag and works well in paraffin wax sections. ${ }^{5}$ Its limitations include lack of specificity and reproducibility. ${ }^{20}$

Antibodies directed against blood group antigens such as $\mathrm{ABO}$ have been suggested as markers of blood vessels, though they are not suitable for routine use as prior knowledge of a patient's blood group is required which is not always available. ${ }^{21}$ Antibodies against cytoskeletal antigens like laminin, found in basement membrane ${ }^{22}$ and vimentin, cannot im-

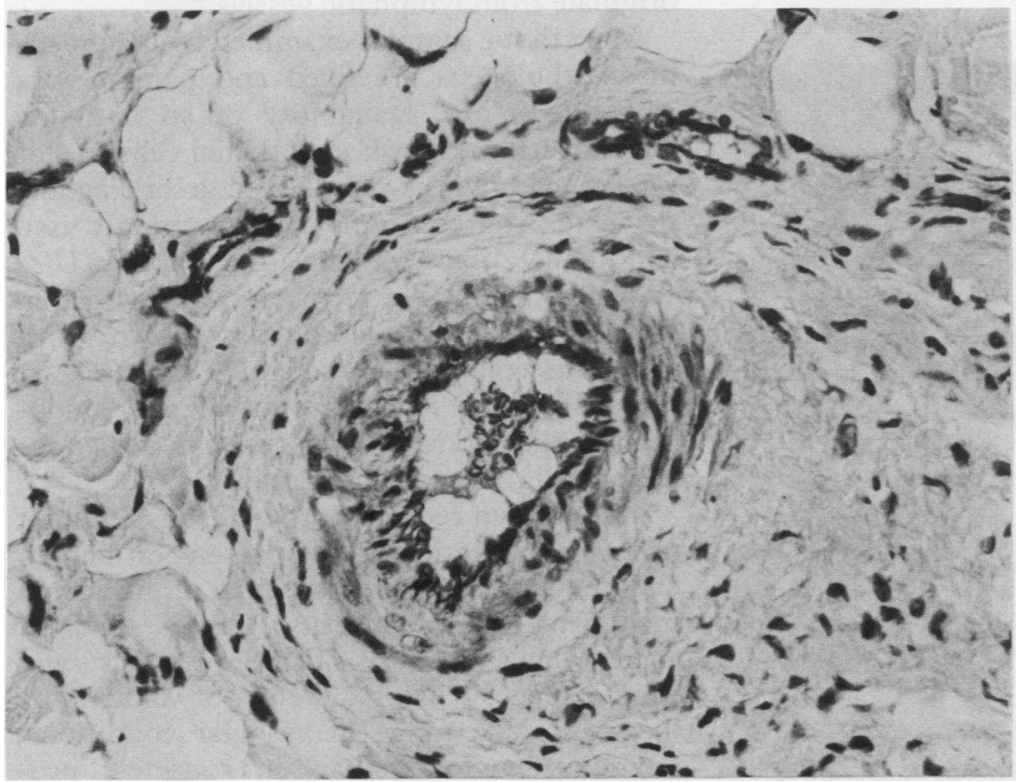

Figures 4-7 Labelling of a variety of normal and neoplastic endothelial cells in trypsinised, paraffin wax sections with antibody JC70 using the APAAP technique.

Figure 4 Aortic adventitial vasa vasorum. prove the immunohistochemical diagnosis of vascular lesions because the antigens are not restricted to endothelial cells.

Monoclonal antibodies, which bind to epitopes of endothelial cell specific antigens, are an alternative to these markers. Those monoclonal antibodies to endothelial antigens which have been reported to date are restricted to frozen or specially fixed tissue because their antigens are not detectable in routinely processed tissue. Monoclonal antibodies in this category include $\mathrm{E}^{23}{ }^{23}$ and PAL-E. ${ }^{24}$ More recently, a monoclonal antibody, BMA 120, has been described which is directed against a formalin resistant endothelial antigen with a molecular weight of 200 kilodaltons. $^{6}$ This molecular weight is similar to that of FVIIIRag, and it is not yet known whether this antibody shares the lack of specificity associated with antibodies to FVIII-Rag.

Antibody JC70 recognises an antigen that is resistant to formalin fixation and which is present on a wide variety of benign vascular endothelial cells. Although JC70 labels a variety of non-endothelial cells in blood smears and cryostat sections, its reactions are essentially restricted to endothelium when fixed tissue is stained. One interesting observation is that JC70 does not stain lymphatic endothelium in benign lesions. Previously reported markers of endothelial cells have not shown this degree of specificity. For example, antibodies to FVIII-Rag have been shown to stain at least a proportion of lymphatics. ${ }^{2}$ Stephenson and Mills have shown that monoclonal antibodies to $A, B$, and $\mathbf{H}$ blood group isoantigens gave strong staining of both lymphatic and vascular endothelium. ${ }^{3}$ On the basis of the results in our study, endothelial cells might be identified as being of lymphatic origin if they are positive for $\mathrm{A}, \mathrm{B}$, and $\mathrm{H}$ blood group isoantigens and FVIII-Rag but unstained by antibody JC70. Further studies on a wider range of lesions containing cells of lymphatic origin are required, however, to support these preliminary findings.

Antibody JC70 also stained occasional 


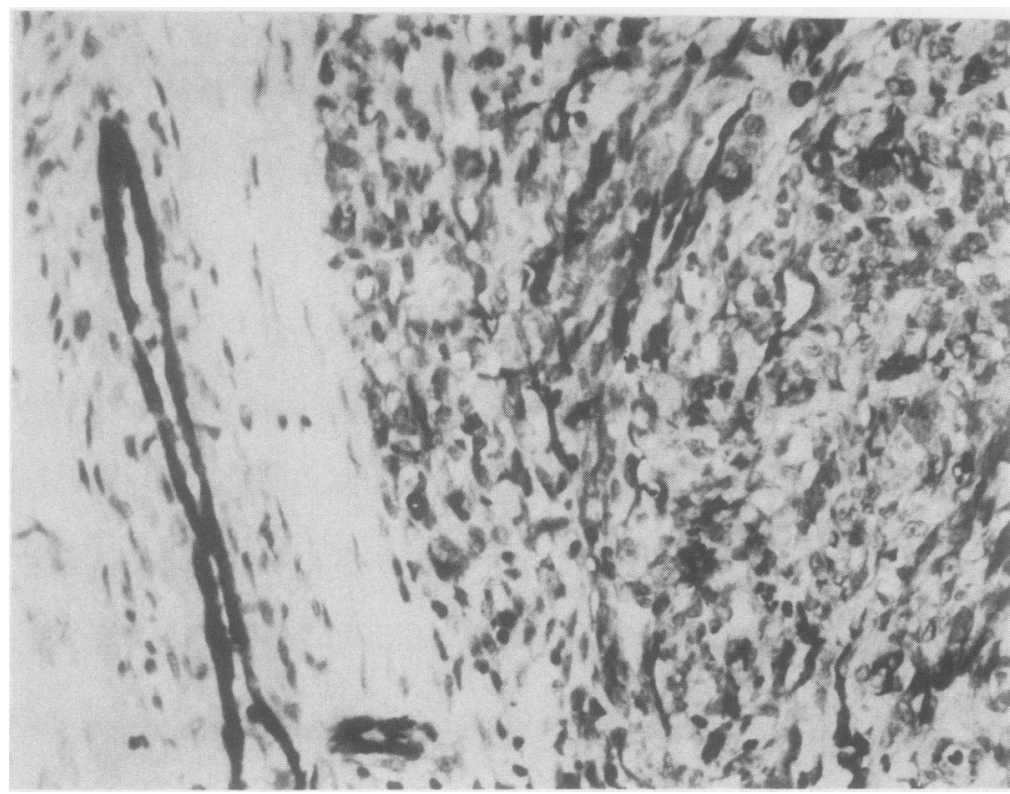

Figure 5 Organising thrombus in a vessel wall with adjacent vasa vasorum.

plasma cells and megakaryocytes in formalin fixed sections. The latter observation may be explained by the fact that endothelial cells contain several proteins, mainly glycoproteins, which are antigenically related to proteins isolated from platelet membranes. ${ }^{25}$ The JC70 antigen is a 100 kilodalton membrane glycoprotein which seems to be identical with the antigen recognised by CD31 antibodies. This has been confirmed by the cloning of cDNA encoding JC70 antigen, which has the same nucleotide sequence as CD31 clones (D Simmons, personal communication). Cells transfected with either CD31 or JC70 cDNA clones are also reactive with both CD31 and JC70 (D Simmons, personal communication). The origin of an antigen band smaller than expected from splenic preparations (100 rather than the 130 kilodaltons of classic CD31) is not known but may be due to proteolytic breakdown or to variations in glycosylation.

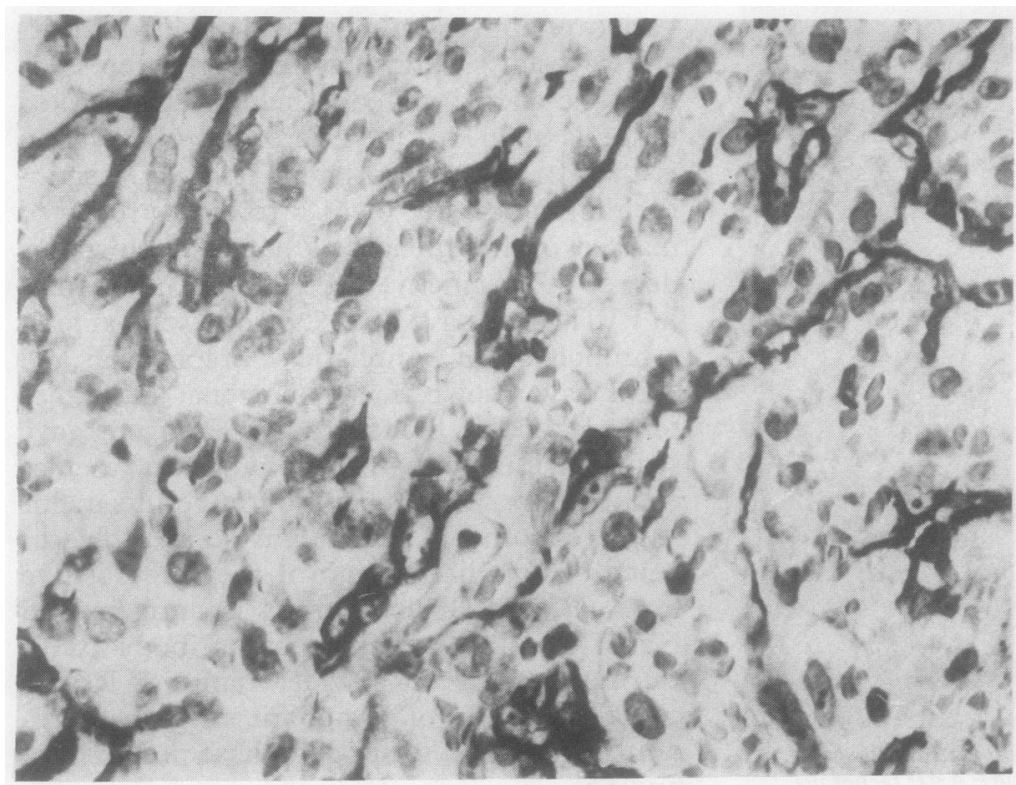

Figure 6 New vessel formation in granulation tissue.
The reaction with atrial myxoma cells supports the endothelial origin of some of these cells. ${ }^{26}$ The staining of both capillary endothelial cells and tumour cells in haemangiopericytoma with the same antibody has not previously been reported and suggests that the endothelial cell and the neoplastic pericyte share at least one antigen in common.

Antibody JC70 stained sinusoidal endothelial cells in liver, lymph node, and spleen. Other workers have shown variable staining of these endothelial cells with Ulex europaeus agglutinin lectin $^{16}$ and antibodies to FVIII$\mathrm{Rag}^{20}{ }^{20}$ indicating that sinusoidal endothelium differs phenotypically from other vascular endothelium. Some workers, however, have shown that hepatic sinusoidal endothelium is Ulex europaeus agglutinin lectin positive in fetal and cirrhotic liver, suggesting a phenotypic change during growth and disease. ${ }^{27}$ The present findings with monoclonal antibody JC70 suggest that the results with these other markers reflect no more than changes in the amount of endothelial antigen present.

Antibody JC70 was more reliable than other markers of malignant endothelial cells because it labelled each of the 10 cases of angiosarcoma tested. JC70 also gave clear, strong staining of these cells unlike the focal and background staining frequently seen with antibodies to FVIII-Rag and Ulex europaeus agglutinin lectin, particularly in areas of necrosis and haemorrhage. The amount of JC70 antigen may be increased on malignant endothelial cells of angiosarcomas, as indicated by the greater intensity of staining of these cells compared with normal endothelial cells.

Kaposi's sarcoma is a spindle cell tumour in which the spindle cells enclose endothelial and non-endothelial lined vascular spaces containing red cells. The lack of staining of spindle cells with JC70 (some of which show positivity with antibodies to FVIII-Rag and Ulex europaeus agglutinin lectin) in sections of Kaposi's sarcoma supports the view that the spindle cells originate from lymphatic vessels. ${ }^{28}$

Most tissue samples examined by diagnostic histopathologists are fixed and paraffin wax embedded. The availability of an antibody which can distinguish endothelial cells in this type of material is potentially of great diagnostic value. At present, the most commonly used endothelial markers are the lectin Ulex europaeus agglutinin lectin and antibodies to FVIII-Rag. As this study has shown, Ulex europaeus agglutinin lectin and FVIII-Rag are less reliable as markers of malignant endothelial cells and may be less specific for endothelial cells of cardiovascular origin.

The antigen recognised by JC70 is resistent to formalin fixation and is present on benign endothelial cells of cardiovascular origin and on malignant endothelial cells. This is apparent even when there is tissue necrosis and haemorrhage. JC70 is therefore of value in the diagnosis of a range of vascular conditions, including angiosarcomas, in routinely processed tissue sections. The range of potential applications of this antibody are likely to be wide. They include the investigation of vas- 

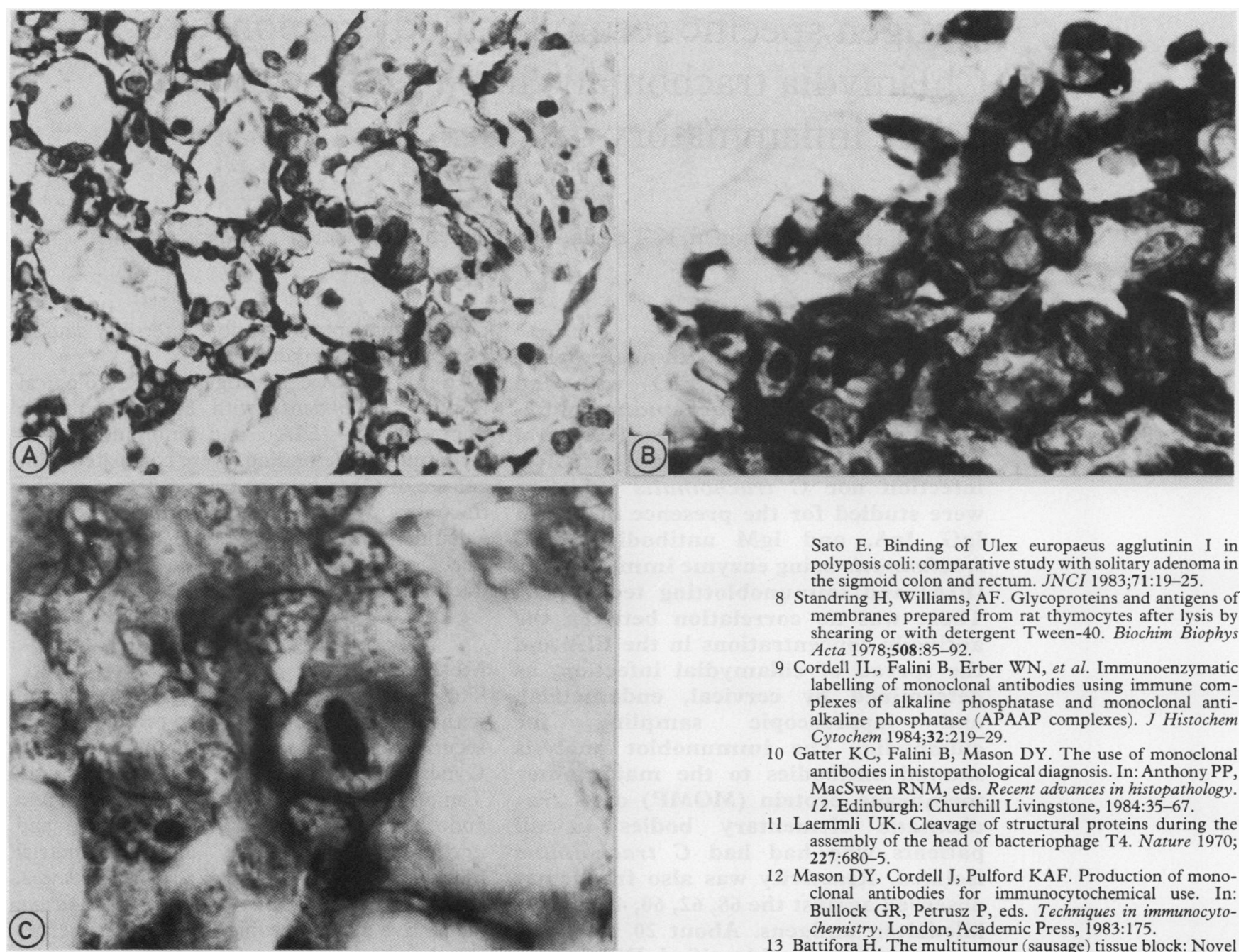

Sato E. Binding of Ulex europaeus agglutinin I in polyposis coli: comparative study with solitary adenoma in the sigmoid colon and rectum. JNCI 1983;71:19-25.

8 Standring H, Williams, AF. Glycoproteins and antigens of membranes prepared from rat thymocytes after lysis by shearing or with detergent Tween -40 . Biochim Biophys Acta 1978;508:85-92.

9 Cordell JL, Falini B, Erber WN, et al. Immunoenzymatic labelling of monoclonal antibodies using immune complexes of alkaline phosphatase and monoclonal antialkaline phosphatase (APAAP complexes). $J$ Histochem alkaline phosphatase (APAA

10 Gatter KC, Falini B, Mason DY. The use of monoclonal antibodies in histopathological diagnosis. In: Anthony PP, MacSween RNM, eds. Recent advances in histopathology. 12. Edinburgh: Churchill Livingstone, 1984:35-67.

11 Laemmli UK. Cleavage of structural proteins during the assembly of the head of bacteriophage T4. Nature 1970; 227:680-5.

12 Mason DY, Cordell J, Pulford KAF. Production of monoclonal antibodies for immunocytochemical use. In: Bullock GR, Petrusz P, eds. Techniques in immunocytochemistry. London, Academic Press, 1983:175.

13 Battifora H. The multitumour (sausage) tissue block: Novel method for immunohistochemical antibody testing. Lab Invest 1986:55:244-8.

Figure 7 Angiosarcoma shown at low power $(A)$ with two different high power fields ( $B$ and $C$ ). cularisation of inflammatory lesions and of tumours, investigation of the development of the placental bed and investigation of the vasa vasorum and neovascularisation of the aortic and arterial intima in relation to atherogenesis.

This work was supported by grants from the Leukaemia Research Fund and the Cancer Research Campaign.
1 Fajardo LF. The complexity of endothelial cells. Am J Clin Pathol 1989;92:241-50.

2 Burgdorf WHC, Mukai K, Rosai J. Immunohistochemical identification of factor VIII related antigen in vascular endothelial cells of cutaneous lesions of alleged vascular nature. Am J Clin Pathol 1981;75:167-71.

3 Stephenson TJ, Mills PM. Monoclonal antibodies to blood group isoantigens: an alternative marker to factor VIII related antigen for benign and malignant vascular endothelial cells. J Pathol 1985;147:139-48.

4 Little D, Said JW, Siegel RL, Fealy M, Fishbein MC Endothelial cell markers in vascular neoplasms: an immunohistochemical study comparing factor VIIIrelated antigen, blood group specific antigens, 6-ketoPGF1 alpha and Ulex europaeus I lectin. J Pathol 1986; 149:89-95.

5 Miettenen M, Holthöfer H, Lehto VP, Virtanen MD. Ulex europaeus I lectin as a marker for tumours derived from endothelial cells Am J Clin Pathol 1983;79:32-6.

6 Alles JU, Bosslet K. Immunocytochemistry of angiosarcomas. A study of 19 cases with special emphasis on the applicability of endothelial cell specific markers to routinely prepared tissues. Am J Clin Pathol 1988;89: routinely prepared tissues. Am J Clin Pathol 1988;89.

7 Yonezawa S, Nakamura T, Tanaka S, Maruta K, Nishi M,
14 Naiem M, Gerdes J, Abdulaziz $Z$, et al. The value of immunohistological screening in the production of monoclonal antibodies. J Immunol Methods 1982;50:145-60.

15 Millard PR, Heryet AR. An immunohistological study of factor VIII related antigen and Kaposi's sarcoma using polyclonal and monoclonal antibodies. J Pathol 1985;146: 31-8.

16 Holthöfer $\mathrm{H}$, Virtanen $\mathrm{MD}$, Kariniemi L, Hormia M, Linder E, Miettinen $H$. Ulex europaeus I lectin as a marker for vascular endothelium in human tissues. $L a b$ marker for vascular

17 Mukai K, Rosai J, Burgdorf WHC. Localisation of FVIIIRag in vascular endothelial cells using an immunoperoxidase method. Am J Surg Pathol 1980;4:273-6.

18 Turner RR, Beckstead JH, Warnke RA, et al. Endothelial cell phenotypic diversity. Am J Clin Pathol 1987;87: 569-75.

19 Millard PR, Chaplin AJ, Heryet AR, McDougall AC. Factor VIII related antigen positive macrophages and acquired immunodeficiency syndrome (AIDS): a problem of antibody specificity. J Clin Pathol 1987;40:262-6.

20 Ordonez NG, Batsakis JG. Comparison of Ulex europaeus lectin and factor VIII-related antigen in vascular endothelial cells using the immunoperoxidase method. Arch Pathol Lab Med 1984;108:129-32.

21 Berry CL, Amerigo J. Blood group antigens in vascular tumours. Virchows Arch (Pathol Anat) 1980;388:167-74. 22 Timpl R, Rohde H, Robey PG, Rennard SI, Foidart JM Martin GR. Laminin-a glycoprotein from basement membranes. J Biol Chem 1979;254:9933-7.

23 Kaplan KL, Weber D, Cook P. Monoclonal antibodies to E92, an endothelial cell surface antigen. Arteriosclerosi 1983;3:403-12.

24 Schlingemann RO, Dingjan GM, Emeiss JJ, Blok J, Warnaar SO, Ruiter DJ. Monoclonal antibody PAL-E specific for endothelium. Lab Invest 1985;52:71-6.

25 Børsum T, Hagen I, Bjerrum OJ. Electroimmunochemical characterization of endothelial cell proteins: antigenic relationship with platelet and erythrocyte membrane proteins. Thromb Haemostas 1987;58:686-93.

26 Johansson L. Histogenesis of cardiac myxomas. Arch Pathol Lab Med 1989;113:735 41 .

27 Petrovic LM, Burroughs A, Scheuer PJ. Hepatic sinusoidal endothelium: Ulex lectin binding. Histopathology 1989 14:233-43.

28 Jones RR, Spaull J, Spry C, Jones EW. The histogenesis of Kaposi's sarcoma in patients with and without AIDS
$J$ Clin Pathol 1986;39:742-9. 